UNRAM Law Review is licensed under a Creative Commons Attribution 4.0 International License, which permits unrestricted use, distribution, and reproduction in any medium, ULRev provided the original work is properly cited. p-ISSN: 2548-9267 | e-ISSN : 2549-2365, Open Access at : http://unramlawreview.unram.ac.id/index.php/ulr

Volume 5 Nomor 1 April 2021

\title{
Marital Rape in a Comparative Perspective of Indonesian Criminal Law and Islamic Criminal Law
}

\author{
Laely Wulandari \\ Law Faculty, University of Mataram \\ Email: laelywulandari01@gmail.com \\ Lalu Saipudin \\ Law Faculty, University of Mataram \\ Email: lalusaipudin@mail.com
}

\begin{abstract}
The aim of this research is to know how the regulation of marital rape in Indonesian Criminal Law and Islamic Law. Marital rape or also known as rape in marriage still belong to such a debatable and taboo topic, but in fact it has happened a lot in society. In Indonesian Criminal Law, marital rape is not regulated in the Criminal Code. The Law on the Elimination of Domestic Violence regulates this as a complaint offense by calling the crime of sexual violence. In Islamic Law, marital rape is regulated in a good way by terms of husband and wife intercourse, among others in Surah An-Nisa Verse 19 which prohibits having to do with coercion. Refers to these results of the comparison, similarities are found in both Indonesian Criminal Law and Islamic Criminal Law that said marital rape is prohibited. The differentials in the form of complaint offense between these laws. Islamic Criminal Law does not explain clearly about the complaints offense as known on Indonesian Criminal Law. Yet this law comprehensibly prohibiting the marital rape itself. For the further regulations of criminal law policies, it should take the principles of discrimination into account and the good boundaries regarding marital rapes, criminal liability, criminal threats and formal criminal arrangements either.
\end{abstract}

Keywords: Marital Rape; Indonesian Criminal Law; Islamic Criminal Law

\section{INTRODUCTION}

Marriage is a new phase of life that experienced by humans. This phase is a combination of man and woman to carry out various commitments with almost the same goals in all marriages, namely a happy and peaceful life without conflict.

Marriage should not have a bad purpose or subordinate one party of the marriage, either the husband or the wife. However, it cannot be denied that sometimes conflicts also arise in marriage. The causes of conflict can vary, either from the married couple itself or the conflict that arises from outside of their household. In case of resolving conflicts, there are several couple who resolve conflicts well so that violence is not used in any conflict arises. On the other hand, there are those who used violence as the only solution to resolve conflicts. After the conflict occurred, there were households that returned to living a life full of love again, but those who failed manage the conflict would unable to maintain their relationship back to the 
track again. There are those who resolve conflicts with violence who bring them to the realm of law and others do not. There are various ways a husband and wife solve the problems that occur in their household.

There are problems between husband and wife which remain in their domestic sphere but some which later become the public domain. Violence that occurs in husband and wife relationships is no longer their domestic domain after the emergence of Law Number 23 of 2014 Concerning the Elimination of Domestic Violence or hereinafter referred to as the PKDRT Law. This law appeared initially because there was a lot of violence against wives done by the husband.

The presence of this law seems to provide fresh air for the resolution of cases of domestic violence in Indonesia. There are signs that must not be violated in living household life. A husband and wife cannot commit violence to each other which results in disharmony in the household, causing victims to be given criminal sanctions. Four types of violence that prohibited in the PKDRT Law are: physical violence, psychological violence, sexual violence and domestic neglect.

Sexual violence regulated in the PKDRT Law means that the PKDRT Law prohibits all types of sexual violence in the household, including sexual violence that occurs between husband and wife. A form of sexual violence is rape that occurs between husband and wife, this is as we known by marital rape. Meanwhile, the Indonesian people are not familiar with the term marital rape and so on, since they think that this kind of issues will never exist.

Most of the Indonesian people embrace Islam. There are some moslem interpret the teaching of serving husbands in Islam as an obligation with violent sanctions. This is because according to that interpretation, serving the husband is the wife's obligation regardless of his wife's condition. This is reinforced by the presence of a hadith narrated by Abu Hurairah which reads: "If a husband takes his wife to his bed but she does not obey it, then the angels will curse her until the morning,"”.

Lack of public understanding of law, both Islamic Law and Indonesian Law, makes marital rape finally occurred in Indonesia. This issue then becomes purpose of researcher to find out the comparison between Islamic Law and Indonesian Law regarding to the regulation of marital rape so that from the results of comparing the advantages and disadvantages of each law can be found a benchmark in criminal law reform in terms of marital rape.

\section{METHOD}

The type of research used in this research is normative or also known as legal research which is focused on examining the application of the rules or norms in the applicable positive law. The approaches that used on this research are statute approach, conceptual approach and also 
comparative approach. These approaches then will be analyzed by deductive method which will leads us to a conclusion. The conclusion is reached reductively by analyzing general rules then narrowing the range under consideration until only special conclusion remains.

\section{ANALYSIS AND DISCUSSION}

\section{Regulations of Marital Rape in Indonesian Criminal Law and Islamic Criminal Law}

\section{Indonesian Criminal Law}

The Criminal Code or hereinafter referred as the KUHP regulates matters related to decency through the second book of the KUHP, especially Chapter XIV. Offenses related to sexual intercourse which is a criminal offense are regulated in Article 285 of KUHP. If the terms on this article is later elaborated, then this article contains several elements, namely: whoever; by force or; by threatening to use force; compel; a woman; having sexual relations outside of marriage; with her.

The party who is forced by violence or threats of violence is a woman who is outside the marriage. The word 'outside of marriage' in this case means a woman who is not his wife. Thus, it becomes clear that marital rape cannot be classified in this article. Basically, KUHP does not regulate the existence of elements of rape in marriage indeed. Therefore, if this incident is later charged by using KUHP, it will be difficult to find articles whose elements meet the criteria of marital rape which developing-around the community.

Since KUHP is not represent the reality nowadays, as a form of further regulation of KUHP, Indonesia then applying the rules that regulates about violences on the household namely PKDRT Law. By this law, based on Article 1, what is meant by household violence is an act against a person, especially a woman, which results in physical, sexual, psychological, and/or neglect of the household, including threats to commit acts, coercion or deprivation of liberty illegally within the scope of household.

PKDRT Law indicate that this law aims to provide protection for its citizens from acts of violence that can be experienced by anyone, even in the house which should be a comfortable shelter for citizens. Starting from the sound of Article 1 of this law, it is written the terms 'especially women' which refers to gender relations. This is because women are attached to the label weak, helpless, second-class creatures, and don't even have rights to themselves. For this reason, although this law was made to protect all sexes, it is prioritized for women.

The PKDRT Law also regulates who is included in the scope of the household as regulated in Article 2 of the PKDRT Law regarding the scope of the household, namely:

a. husband, wife, and children; 
b. people who have a family relationship with someone like that referred to in letter (a) because of blood relations, marriage, care and guardianship who live in the household; and/or

c. the person who works helps the household and lives in the household.

Furthermore, there are four types of violence regulated through Article 55 of the PKDRT Law, namely:

1) physical abuse;

2) psychic violence;

3) sexual violence; and

4) neglect of the household.

Beside the psychological violence which is a new type of violence regulated by law, sexual violence in the PKDRT Law is also interesting to studied further since the terms of marital rape actually arises by this regulation. Article 5 in juncto Article 8 of the PKDRT Law does indeed provide a new discourse in handling the issue. Article 8 of the PKDRT Law stated:

Sexual violence as referred to in Article 5 letter c includes:

a) forcing sexual intercourse carried out on people who live within the scope of the household;

b) forcing sexual relations between one person within the scope of his household with another for commercial purposes and / or certain purposes.

Based on Article 8, it said that PKDRT Law does not only regulate act of rape that committed by husbands against wives, but all of those within the scope of the household as regulated in Article 2 of the PKDRT Law. Thus, not only a husband who could rapes his wife, but also a father who rapes his child, an older brother who coerces sexual intercourse with his younger sibling, or sexual intercourse donebythe household parties to the household assistant, this whole phenomenon is included in the provisions of the PKDRT Law. In this case, the PKDRT Law comprehensively accommodates more regulations regarding marital rape than the KUHP.

Article 8, especially on letter a, of PKDRT Law contains several elements,namely:

(1) Coercion of sexual relations

The word coercion means that there is one party who does not like having sexual relations carried out. So sexual relations are carried out with unbalanced relationships; and

(2) Conducted on people who live within the scope of the household

The victims of forced sexual relations have been determined, namely those who are within the scope of the household as stated in Article 2 of this Law.

Against this Article 8 of the PKDRT Law the author provides two analyzes. Firstly, the criminal act of sexual relations as referred to in Article 8 does not clearly regulate whether the sexual relationship in question is sexual intercourse or about sexual immorality. Referring to Article 284 of KUHP concerning intercourse, as regulated in Hoge Arrest 5 February 1912, there is a complaint between male and female genitalia that is usually carried out to have 
children, so male members must enter into female members, thus issuing semen. ${ }^{1}$ Thus, if these elements are not fulfilled, then this sexual relationship can refer to the obscenity of Article 289 of the Criminal Code.

Secondly, there is no requirement for violence or threats of violence in Article 8, which are listed as only coercive. This kind of actions can be done with deeds and can also be done with words. Therefore, there is no requirement for violence. It could be done by trickery. The criminal threat against this article is contained in Article 46 which stated that:

Every person who commits an act of sexual violence as referred to in Article 8 letter a, shall be subject to imprisonment for a maximum of 12 (twelve) years or a maximum fine of IDR 36,000,000.0 (thirty six million rupiah)

If this provision occurs between husband and wife, it is included in the complaint offense. This is stated in Article 53 which said:

The criminal act of sexual violence as referred to in Article 46 which is committed by a husband against his wife or otherwise constitutes a complaint offense.

This means that marital rape will never become a crime if it is not complained by the wife. So even though the issue of marital rape has been regulated in the PKDRT Law, it is still not fully a public affair.

\section{Islamic Criminal Law}

Islamic Criminal Law is part of Islamic Law or Fiqh in general which is a discipline of knowledge about islam or sharia, where the basic teachings of islam include three main aspects, namely: iman; islam; and ihsan. These three main aspects require three different disciplines. The science of faith or creed is called the science of tawhid, the science of islam or sharia is called fiqhand the knowledge of ihsan or morals is called tasawuf. Islamic Criminal Law is a translation of jinayah fiqh which is one of the six branches of fiqh in Islamic law. The six branches of fiqh are the fiqh of worship, muamalah, munakahat, jinayah, siyasah, and mawaris. ${ }^{2}$

The criminal act of rape in Islamic Law is called by $A l$ Wath 'u Bi Al Ikraah. If a man rapes a woman, the entire fuqaha agrees that the woman will not be subject to zina punishments in islam, either 100 lashes or rajam. In Islamic law, it is crystal clear that we could not find any form of punishment for the behavior of forcing sexual relations between husband and wife. The form of punishment that does exist is the regulation of sexual relations outside the place, such as having sex through the rectum. In this case the jurists had different opinions in imposing criminal sanctions. According to Imam Abu Hanafi, the perpetrator was sentenced to ta'zir because it was not considered adultery on the grounds that he interfered with women through faraj who were eaten with adultery while those who passed through the rectum were

${ }^{1}$ R. Soesilo, (1994). Kitab Undang-Undang Hukum Pidana (KUHP) serta Komentar-KomentarnyaLengkapPasal Demi Pasal. Bogor: Pasal, Politea, p. 209

${ }^{2}$ Ibid. p. 2 
named liwath. Meanwhile, according to Imam Malik and Imam Syafi'i, the perpetrators were still sentenced to had punishment on the basis of qiyas, namely diqiyaskan with adultery. ${ }^{3}$

Rape in marriage according to Islamic Law is not clearly regulated, however, a good husband and wife relationship in Islamic Law must be based on the principle of Musyarahbi Al-Ma'ruf or good relationship between husband and wife. Husbands are obliged to treat their wife well, not to force, disturb or hurt them. ${ }^{4}$ Related to this terms, it can be seen in the arrangement of the Al Qur'an by the following verses:

a. Qur'an SurahAr-Rum (21)

And among His signs (greatness) is to create partners for you of your own kind, so that you are inclined and feel at peace with him and He makes among you a sense of affection.

b. Qur'anSurah An-Nisa(19)

"... and hang out with them byma'ruf,".

c. Q.S Al-Baqarah (228)

“....and they (women) have rights in proportion to their obligations in an appropriate manner (ma'ruf) and for the husbands have advantages over them..."

The relationship between husband and wife in islam has been arranged in such a way as to respect each other and treat each other well. The sentence "....and hang outwith them by ma'ruf" implies that it is not permissible to have sexual intercourse if it could cause harm to his wife. The necessity to have sex with a wife in a ma'ruf way applies to the husband in every situation. This can be understood from the continuation of the Verse 19 above:

“...maka bersabarlah karena mungkin kamu tidak menyukai sesuatu Padahal Allah menjadikan padanya kebaikan yang banyak..."

In full and firmly this surah said:

O you who believe it is not lawful for you to destroy women by force and do not trouble them because you want to take back some of what you have given them, unless they do real heinous work and associate with them properly. Then if you don't like them (then be patient) because maybe you don't like something, even though Allah makes a lot of good rewards

The above verses are reinforced by the results of the Indonesian Ulema Women's Congress on April $25^{\text {th }}-27^{\text {th }} 2017$ in Pondok Jambu, Cirebon, West Java, which has confirmed that the law of sexual violence, both outside and inside of marriage, is haram. This religious attitude has become an important milestone in the Islamic discourse on rape in marriage. ${ }^{5}$ Thus, it can be concluded that in Islamic law marital rape is also undesirable and the law is haram. However,

\footnotetext{
${ }^{3}$ Mustafa Daib al-bigha dalam Muhammad Yunus. (2018). Marital Rape (perkosaan dalam perkawinan) ditunjau dari perspektif Hukum Islam dan Hukum Indonesia, Program Studi Perbandingan Mazhab Fakultas Syari'ah dan Hukum. Jakarta: Unversitas Negeri Islam Negeri Syarif Hidayatullah.

${ }^{4}$ Septianita azalea, Marital Rape dalam Pandangan Islam, 29 april 2020, apikartini.org, diaksestanggal 14 oktober 2020

${ }^{5}$ Nur Rofiah, The conversation.com. Larangan Islam atas pemerkosaan dalam perkawinan, diakses tanggal 20 Oktober 2020
}

48 Laely Wulandari \& Lalu Saipudin | Marital Rape in Comparative Perspective... 
unlike in Indonesian Criminal Law, Islamic Criminal Law in the case of marital rape does not explicitly determine the sanctions.

\section{Future Criminal Law Policies Related To Marital Rape Arrangements}

Criminal law recognized term namely criminal law policy. This policy came from english, namely policy, or also dutch, namely politiek. Refers to these foreign terms, the term criminal law policy itself can also be referred as criminal law politics. Sudarto explained that what is called as legal politics consists of several elements, namely: ${ }^{6}$

a. attempts to create good regulations in accordance with the circumstances and situations at a particular moment; and

b. the policy of the state through the authorized bodies to determine the desired regulations that are thought to be used to express what is contained in society and to achieve what it aspires to be.

Refers to these elements, Sudarto further stated that implementing the politics of criminal law also means holding elections to achieve the results of best criminal legislation that meet the requirements of justice and efficiency. The use of criminal means must always take into account the precautionary principle because of the offensive nature of the criminal law by the existence of criminal sanctions. The determination of an act or deed to be a criminal act or action must pay attention to the principles of good criminalization.

Ted Honderich believes that a crime can be called an economic deterrent if the following conditions are met: ${ }^{7}$

1. criminal really prevents;

2. the crime does not cause a situation more dangerous or detrimental than that which would have occurred if the sentence was imposed; and

3. there is no other crime that can prevent it effectively with less harm or loss.

From the signs of criminalization above, it can be analyzed whether an act stipulated in a law becomes a criminal act that meets the criteria of "a good crime". To determine marital rape as a crime, it is necessary to understand the signs of crime above. It is wiser to prevent this determination of criminal act lead to a new crime. The importance of regulating marital rape as a criminal offense that has sufficient reasons.

Apart from the fact that the number of marital rape in Indonesia shows a significant development, yet the regulations on marital rape itself stillnot balancing the cases. Referring to the results of the comparison of Indonesian Criminal Law and Islamic Criminal Law above, it is clear that both in those laws, marital rape is not an act that is justified. However, to make marital rape a crime, the principle of criminalization in criminal law politics must be considered so that it does not cause a new problem.

\footnotetext{
${ }^{6}$ Sudarto. (1981). Hukum dan Hukum Pidana. Bandung, Alumni, p.159

${ }^{7}$ Ibid, p. 35
} 
In the PKDRT Law, according to the compilers, the weakness is that marital rape is still regulated as a complaint offense, while in Islamic Criminal Law even the results of ijma stated that "the scholars state that marital rape is haram without any clarity on how actions can be taken against both the perpetrator and the victim,". For this reason, the next criminal law policy should be implemented clearly that:

a) clear boundaries for an act are called rape in marriage;

b) criminal responsibility;

c) criminal threat; and

d) formal punishment.

These four main points must be stated in regulations that do not lead to further interpretations and do not create potential conflicts in their application, so that signs of criminality in the politics of criminal law are achieved.

Draft of the 2019 KUHP, or hereinafter referred as RUU KUHP, accommodates regulations regarding rape in marriage in Article 480, namely:

1) anyone who by force or threat of violence forces someone to have intercourse with him, shall be punished for committing rape, with a maximum imprisonment of 12 years;

2) includes the crime of rape and the punishment as referred to in point a includes the following actions:

a) intercourse with someone because of his consent, because that person believes that he is a legal husband and wife;

b) copulation with children; and/or

c) intercourse with someone even though it is known that the person is unconscious or helpless.

Article 480 (1) provides that anyone who by force or threat of violence forces someone to have intercourse with him, shall be punished for committing rape. In contrast to Article 285 which requires that outside of marriage, this article no longer includes the phrase outside of marriage. This means that this rape can occur in relationships within or outside of marriage. Even though it is different from the Criminal Code and gives such a fresh air to the regulation of marital rape, the RUU KUHP also added the word “...both outside of marriage and in marriage ties..." so that what is desired becomes clear and does not lead to interpretations.

Apart from the RUU KUHP, Indonesia currently has a Draft on the Elimination of Sexual Violence or hereinafter referred as the RUU PKS. The RUU PKS ever been the subject of final discussion in the People's Representative Councilbut was later postponed for re-discussed. One of the articles that caused controversy was the article on marital rape. For the same reason, there are still many who argue that rape in marriage is an impossible thing or taboo to be discussed. 
RUU PKS regulates the definition of sexual violence as: ${ }^{8}$

Every act of humiliating, insulting, attacking, and or other actions against one's body, sexual desire and/or reproductive function, forcibly contradicts someone's will which causes that person to be unable to give consent in a free state, due to imbalances in power relations, and/or gender relations. which results or can result in physical, psychological, sexual suffering or suffering. Losses economically, socially, culturally and or politically.

Thus, the RUU PKS regulates in detail how sexual violence is by stating how the act was committed, what the consequences were and the cause for the act being committed. Compared to the RUU KUHP or the old KUHP, it is clear that the RUU PKS is more detailed in regulating the definition of sexual violence. In addition, the RUU PKS also regulates the act of prevention. This is as shownon Article 6 Paragraph (1) that said "includes material on sexual violence as teaching material, in the non-curricular or extra-curricular curriculum from early childhood education to tertiary education,".

Regarding to the issue of marital rape, the definition is not clearly regulatedbut presumably the RUU PKS accommodates the regulation on the prohibition of sexual violence. This is as stated in Article 11 which said:

(1)everyone is prohibited from committing sexual violence;

(2)sexual violence as stipulated on point a consists of:

(a) sexual harassment;

(b)sexual exploitation;

(c)forced contraception;

(d)forced abortion;

(e)rape;

(f) forced marriage;

(g)forced prostitution;

(h)sexual slavery; and/or

(i) sexual torture.

(3)sexual violence as referred to in point a includes incidents of sexual violence within the scope of personal, domestic, work relations, public relations and or other special situations.

The RUU PKS regulates the scope of the relationship for the conduct of these acts. Regarding to marital rape, it is clearly stated in the article that the scope of the household is also included in it. Therefore, actually for future regulation, Indonesia already has an adequate regulatory concept regarding marital rape. However, just a concept is not sufficient for legal protection in

\footnotetext{
${ }^{8}$ Pasal 1 ayat (1) RUU PKS
} 
Indonesia. Thus, if we have rules that really accommodate the issue of marital rape which is accompanied by a strong desire from various parties to fight against marital rape.

\section{CONCLUSION}

Both Indonesian Criminal Law and Islamic Law equally prohibiting the act of marital rape. In Indonesia, marital rape regulated in the Law on the Elimination of Domestic Violence, especially Article 5 juncto Article 8 in the form of a complaint offense, while in Islamic law it is regulated in Surah An-Nisa Verse 19 and strengthened by Ijma Ulama in Indonesian Women Conferences. The difference is that in the Indonesian Criminal Law, the criminal rules are regulated in Article 47 of the PKDRT Law, while in Islamic Criminal Law it does not clearly state what the conviction of perpetrators what marital rapes is.

Criminal law policies in the future should clearly regulating about marital rape comprehensively by taking into account the signs of discrimination against an act so that marital rape is no longer considered as a husband's right to have intercourse with his wife in any way. For that, it is necessary to regulate : $a$. Definition of the crime; $b$. The criminal responsibility; $c$. The threat of punishment; and d. Formal criminal arrangements.

\section{Bibliography}

\section{Books:}

Andi Hamzah. (2012). Perbandingan Hukum PidanaBeberapa Negara. Jakarta: Sinar Grafika, Ann Brooks. (1997). Posfeminisme dan Culture Studies, Yogyakarta: Jalasutra.

Barda Nawawi Arief. (2013). Perbandingan Hukum Pidana. Jakarta: Rajagrafindo Persada.

------. (2005). Beberapa Aspek Kebijakan Penegakan dan Pengembangan Hukum Pidana. Bandung: Citra Aditya Bakti.

------. (2005). Bunga Rampai Kebijakan Hukum Pidana. Bandung: Citra Aditya Bhakti.

Beni Ahmad Saebani. (2016). Perbandingan Sistem Hukum Pidana. Bandung: Pustaka Setia,

Darji Darmodiharjo dan Shidart. 1996. Penjabaran Nilai-Nilai Pancasila Dalam System Hukum Indonesia. Jakarta: Raja Grafindo.

Chairul Huda. (2006). Dari Tiada Pidana Tanpa Kesalahan Menuju Kepada Pertanggungjawaban Pidana Tanpa Kesalahan. Jakarta: Kencana.

Esmi Warasih, Pranata hukum sebuah telaah sosiologis, Suryandaru Utama Semarang, 2005

Forum Kajian Kitab Kuning (Fk3). (2003). Wajah Baru Relasi Suami Istri, Telaah Kitab 'uqud al Lujjayn. Yogyakarta: Lkis.

Hamdanah. (2005). Musim Kawin di MusimKemarau, StudiatasPandangan ulama Jembertentanghak-hakreproduksi Perempuan. Yogyakarta: Bigraf Publishing.

M. Nurul Irfan, Hukum Pidana Islam, Sinargrafika Jakarta, 2016

52 Laely Wulandari \& Lalu Saipudin | Marital Rape in Comparative Perspective... 
Mustafa Daib al-bigha dalam Muhammad Yunus. (2018). Marital Rape (perkosaan dalam perkawinan) ditunjau dari perspektif Hukum Islam dan Hukum Indonesia, Program Studi Perbandingan Mazhab Fakultas Syari'ah dan Hukum. Unversitas Negeri Islam Negeri Syarif Hidayatullah, Jakarta.

Peter de Cruz. (2012). Perbandingan Sistem Hukum Common Law, Civil Law dan Sosialist Law. Bandung: Nusa Media.

P.A.F Lamintang dan Theo Lamintang. (2011). Delik-Delik Khusus Kejahatan Melanggar Norma Kesusilaan dan Norma Kepatutan. Jakarta: Sinar Grafika.

Ratna Megawangi. (1999). Membiarkan Berbeda, Sudut Pandang Baru Tentang Relasi Gender. Bandung: Mizan.

Ronni Rahman Nitibaskara. (2018). Ragam dan Jenis Kejahatan Kontemporer Di Indonesia. Jakarta: UMJ Press Publishing.

Romli Atmasasmita. (2009). Perbandingan Hukum Pidana. Bandung Mandar Maju,

Ridwan M. AG. (2206). Kekerasan Berbasis Gender, Pusat Studi Gender. Purwokerto: Sekolah Tinggi Agama Islam Negeri (STAIN).

R. Soesilo. (1994). Kitab Undang-Undang Hukum Pidana (KUHP) serta KomentarKomentarnya Lengkap Pasal Demi Pasal. Bogor: Politea

Topo Santoso. (2000). Mengagas Hukum Pidana Islam, Penerapan Sariah Islam dalam konteks Modernitas. Bandung: Asy Samsul, ,

\section{Journal articles:}

Titin Samsudin, Marital Rape sebagai Pelanggaran Hak Asasi Manusia, Jurnal: Al-Ulum, Volume 10, Nomor 2 Desember 2010, p. 339-354

Evy SeptianaRachman, Marital Rape dalam Perspektif Hukum Islam (Kajian Epistimologi) Jurnal Ilmu Hukum: Justicia Sains, Vol, 04 no. 01 Juni 2019

\section{World Wide Web:}

Fajri M. Muhammad, S.H, LLm. PhD. Islam dan Marital Rape, Antara Kesalahfahaman dan Kebenarfahaman, Thisisgender.com, diaksestanggal 20 Februari 2020

Nur Rofiah, The conversation.com. Larangan Islam ataspemerkosaandalamperkawinan, diakse stanggal 20 oktober 2020.

Elang M.L. Marital Rape dalam Perspektif Hukum Islam, www. Kompasiaa.com. diakses tanggal 21 Februari 2020

Septianita Azalea, Marital Rape dalam Pandangan Islam, 29 april 2020, apikartini.org, diakses tanggal 14 oktober 2020. 